\title{
Abundance and Distribution of Climbers in a Coastal Hill Forest in Perak, Malaysia
}

\author{
S. Ghollasimood (Corresponding author) \\ Faculty of Agriculture, Birjand University, Iran \\ I. Faridah-Hanum, M. Nazre \& Abd Kudus Kamziah \\ Faculty of Forestry, Universiti Putra Malaysia, 43400, Serdang, Selangor, Malaysia \\ E-mail: sghollassi@yahoo.com
}

Received: November 30, 2011

Accepted: December 15, $2011 \quad$ Online Published: April 1, 2012

doi:10.5539/jas.v4n5p245

URL: http://dx.doi.org/10.5539/jas.v4n5p245

\begin{abstract}
Species diversity and density of all climbers were inventoried in five 1-hectare plots (at $45 \mathrm{~m}$ to $350 \mathrm{~m}$ elevations) in a coastal hill forest of Pulau Pangkor in Perak. In addition, we analyzed pattern of community diversity using species richness and evenness. Total of 4901 climbers belonging to 45 species were recorded. Mean climber density was 870 stems per ha. Annonaceae, Connaraceae and Menispermaceae were the most species-rich plant families of climbers followed by Rubiaceae and Leguminosae. Twiners formed the bulk (64\%) of climber types followed by hook climbers and tendril, while root climbers were rare. Results from Canonical Corresponding Analysis (CCA) indicate that altitude was the most important factor that influenced the abundance and distribution of climbers.
\end{abstract}

Keywords: Climber, Climbing mechanism, CCA ordination, Coastal hill forest, Malaysia

\section{Introduction}

In the past decades, most studies carried out on vascular plants, despite the fact that the non-tree vegetation is responsible for a high percentage of the total diversity in the tropical forests (Gentry and Dodson 1987, Schnitzer and Carson 2001).

Climbers are an abundant and diverse life-form in most tropical forests and their presence is often a key physiognomic feature differentiating tropical from temperate forests (Reddy and Parhasarathy 2003, Schnitzer and Bongers 2002, Nabe-Nielsen 2001, Perez-Salicrup et al. 2001). Climbers rely on other plants for mechanical support, the amounts of supporting tissue in their axes have reduced to provide higher hydraulic conductivity in their stems and invest resources in growth of length while tree allocate resources to supportive tissue (Gillepsi 2000).

Climbers contribute substantially to the floristic, structural and functional diversity of tropical forests (Benavides et al. 2005), where they can compete with other vegetation. For example, they compete with trees for both above and below-ground resources, considerably decreasing the growth rates, retarding regeneration of tree seedlings and saplings, and increasing the number of trees damaged and killed in treefalls (Stevens 1987, Schnitzer et al. 2005, Pérez-Salicrup 2001, Grauel Putz 2004, Kainer et al. 2006). Climbers can also have positive effects on forests, providing valuable food resources, habitat, and connections among tree canopies that are used as pathways by arboreal animals (Emmons and Gentry 1987, Ødegaard 2000). Climbers may also play a role at the ecosystem level by contributing to the carbon budget of tropical forests, representing as much as $10 \%$ of fresh aboveground biomass (Putz 1984).

Although some climbers merely lean on and spread over other plants, the majority have special shoots to find a means of support, i.e., shoots with twining stems; these include stem as well as branch twiners where, either the tip of the young stem is able to revolve so that the plant becomes securely wound round its supports or the leaf bearing branches twine around the supports. Hook climbers; these possess hooks that passively assist them in climbing or lean on the hosts without attachment. Rooting climbers or adventitious roots; attachment is by means 
of aerial roots and they cling to the surface over which the plant grows. Tendril climbers; possess organs of varied morphology, sensitive to contact with a support to which they fix themselves actively, usually by curling round it rattans (climbing palms) possess curved spines, which help in attachment to supports (Padaki 2000). These specialized shoots are often called searcher shoots because they search for supporting structures (Putz and Holbrook 1991). Having a long stem increases the probability that a searcher shoot will encounter a suitable support (Cai et al. 2007, Selaya et al. 2007, Selaya and Anten 2008). Most of these climbing types can be found in any tropical forest but some strategies appear to be better than others (DeWalt et al. 2000).

Since Putz's work (1984), climbers have been of major concern in tropical ecology and biodiversity conservation. A few studies on climbers diversity and ecology in forest ecosystems have been particularly carried out in the Peninsular Malaysian states and Sabah (Proctor et al. 1983, Putz and Chai 1987, Campbell and Newbery 1993, Appanah et al 1993, Kammesheidt 2009).

The specific objectives of the present study were to compare taxonomic diversity, abundance and diversity of climbers.

\section{Methods and Materials}

\subsection{Study Area}

This study was performed in Sungai Pinang Permanent Forest Reserve in Pulau Pangkor (Figure 1), an island located on the west coast of Peninsular Malaysia between $04^{\circ} 13.0^{\prime} \mathrm{N}$ latitude and $100^{\circ} 33.0^{\prime} \mathrm{E}$ longitude. It is one of the famous and well known island in Malaysia with area of eight square kilometres and classified as coastal hill forest with a high conservation. The climate is typically humid tropical and seasonal heavy rain, February and March are the driest months, mean annual rainfall is $1820.23 \mathrm{~mm}(2000-2010)$. The highest mean temperature is in February to May (average $27.65^{\circ} \mathrm{C}$ ) and the minimum occurs during September to December (average $26.8^{\circ} \mathrm{C}$ ) (Sitiwan Station, Perak 2010). The elevation of the study area ranges from 45 to $350 \mathrm{~m}$ above the sea level.

\subsection{Data Analysis}

Five plots of 1-ha (each $100 \times 100 \mathrm{~m}$ ) were established and subdivided into 100 subplots of $10 \times 10 \mathrm{~m}$ between 45 and $350 \mathrm{~m}$ above sea level. Each subplot was systematically surveyed by enumerating, identifying and measuring the diameter at breast height $(\mathrm{DBH} \geq 1 \mathrm{~cm})$ of all climbers. Samples of each species were collected to be maintained in herbarium of Forestry Faculty, Universiti Putra Malaysia (UPM). Climbing mechanisms were also studied for each species. We classified species by climbing mechanism based on observations in the field and reliable references (Putz 1984). Totally 45 soil samples from the centre of each subplot were collected with $30 \mathrm{~cm}$ hammer corer and soil texture analyzed by Bouyoucos method in order to determine the percentage of sand, silt and clay at the Soil Laboratory in Faculty of Forestry, UPM.

Differences of species richness and abundance between plots were analyzed by ANOVA. Kruskal-Wallis test was used to find the differences between soil particles. A canonical correspondence analysis (CCA) was carried out with PC-ORD (version 4.14, MJM Software; McCune and Mefford, 1999) to analyze the relationships between climbers abundance and environmental parameters (soil type and elevation).

\section{Results}

\subsection{Species Composition}

The study area contained a total of 4903 climbers in 45 species belong to 37 genera within 20 families, unidentified climbers accounted for only $0.06 \%$ of all stems sampled and mean density was 870 stems per ha. There was a significant variation in the density of species and number of individuals $(\mathrm{P}<0.002, \mathrm{P}<0.0009)$ within five plots (Table 1). When the number of species per family were compared, Palmae (6 species, 3 genera), Annonaceae ( 5 species, 5 genera), Connaraceae ( 5 species, 2 genera), Menispermaceae ( 5 species, 4 genera) were the dominant family followed by Rubiaceae ( 4 genera, 4 species) and Leguminosae (3 species, 3 genera). The most species rich genera was Connarus and Calamus with 3 species, followed by Rourea, Tetracera, Strychnos and Coscinium having two species each, while the remaining 28 genera each represented by only one species. The largest climber (dbh $>30 \mathrm{~cm})$ were Scindapsus perakensis and Tinomiscium petiolare, which mostly appeared in the first plot at lower elevation. Calamus javensis was the dominant species, accounting for $26 \%$ of total individuals followed by Daemonorops calicarpa (12\%), Dalbergia parvifolia (10\%) and Rourea rugosa (5.6\%).

Dalbergia parviflora, Paederia foetida and Tinomiscium petiolare were only few species, which frequently attained height canopy. The species, which found in all plots are including: Calamus javensis, Connarus ferrugineus, C. gris, Dalbergia parviflora, Gnetum microcarpum, Rourea mimosoides, R. rugosa, Spatholobus 
ferrugineus, Strychnos axillaris, $S$ flavescens and Tinomiscium petiolare. The number of unique species (occurring in only one plot) in the first plot were 4 species including Artabotrys suaveolens and Ellipeia cuneifolia (Annonaceae), Gomphia microphylla (Ochnaceae), Epipremnum giganteum (Araceae), Piper magnibaccum (Piperaceae) and Adenia penangiana (Passifloraceae) in the fourth plot. Apocynaceae, Combretaceae, Dichapetalaceae, Dioscoraceae, Genetaceae, Linaceae, Ochnaceae, Passifloraceae, Piperaceae, Rhamnaceae and Vitaceae were represented by only one species each. Figure 2 shows the percentage of climber families in the study area. Palmae, Leguminosae and Connaraceae were the most abundant families according to the number of individuals.

According to the Bouyoucos analyses, the type of the soil was mainly sandy (Table 2). The CCA illustrates the distribution of subplots and climbers according different elevations (Figure 3,4). The second and third axes of CCA explain $56 \%$ of the cumulative variance in species data, indicating that, elevation had the highest correlation with axis 2 and $3\left(\mathrm{r}^{2}=-0.4, \mathrm{P}<0.0001 ; \mathrm{r}^{2}=-0.16, \mathrm{P}<0.001\right)$ which may strongly influence the climbers' distribution patterns, while soil type was not significant and showed no correlation with climber density $\left(\mathrm{r}^{2}=0.009, \mathrm{P}>0.85\right)$. According to CCA results, some species were common to all elevations; some unique species emerged in special elevation. Low elevations were characterized by richness of species like Connarus semidecrus, Uvaria griflora, Gnetum microcarpum and Dalbergia parviflora. Common species in high elevation were Coscinium blumeanum, Coscinium fenestratum, Spatholobus ferrugineus and Dioscorea bulbifera. A group of species such as Willughbeia edulis, Paederia foetida, Uncaria cordata, Roucheria griffithiana, and Daemonorops calicarpa were found on average elevation.

\subsection{Climbing Mechanisms}

Climbing mechanisms differ significantly among the five plots $(\mathrm{p}<0.0001)$ (Appendix 1). Generally, all climbers encountered in the study areas possess one of five major mechanisms of climbing. This difference in the number of climbing types between plots corresponds with the difference in species richness of climbers. Twining was the predominant climbing mechanism in all plots (58\%) of species, followed by hook (16\%) while $14 \%$ were rattan. The other two types of climbing mechanism were less common between, (4.5\%) roots climbing the host plants and $(7 \%)$ used tendrils.

Only a few species, mainly in the genus Scindapsus and Piper used roots to climb host plants. Twiners, hooks, tendrils and rattan occurred in all five plots and root climbing was disappeared in plots 2 and 5. In general, there were a greater proportion of twiners in all plots. Table 3 and 4 show the number of species and the distribution of individuals according to climbing types.

\section{Discussion}

Compared to many published studies, we found relatively high climbers abundance and diversity in this study area. With a mean abundance of 870 per hectare and 45 species, climber abundance and diversity in Pulau Pangkor was similar to, or higher than that of other tropical Asian forests. For example, at Lambir Hills in Sarawak, northwestern Borneo, mean climber abundance was 348 per ha in valley and hilltop site (Putz and Chai 1987).

In the Danum Valley Conservation Area in Sabah, northeastern Borneo Campbell and Newberry (1993) found 882 individuals per ha of lowland dipterocarp forest. In five forests in Southern India, Parathasarathy and co-workers found on average 345 climbers per ha in a total sample area of 47 ha (Muthuramkumar and Parathasarathy 2000, Parathasarathy et al. 2004). At Sepilok Forest Reserve, Malaysia, DeWalt et al. (2006) found average 1348 climbers per ha in three forest types.

The difference in the number of climbing types between the plots corresponds with the difference in species richness of climbers and hosts. The majority of climber species occurred in the first plot. As the number of plots increased, the number of climbers reduced. Climbers thought to be light demanding because of their rapid growth in high light. Climbers in the early phase of growth need light to germinate and light availability may constrain their establishment and growth (Putz and Appanah 1987, Teramura et al. 1991) so less climber density may be attributed to the presence of emergent and other early-successional species like the dipterocarps due to increasing canopy height (Baars et al. 1998). Ter Steege and Cornelissen (1989) explained both light and water availability for the distribution of climbers. Water was more important at low altitude (Sang 2009). Richards (1996), however, considers the availability of light more than the humidity. During tropical forest succession, the forest structure light environment change. The distribution of tree diameters becomes more variable, canopy height increases, light levels at the ground decrease. The density of trees decreased slightly with increasing altitude while mean tree dbh increased (Homeier et al. 2010, Richards 1996). 
Homeier et al. 2010, Leimbak 2001, Parthasarathy 2004, Senbeta et al. 2005, Zhu 2008 and Balfour and Bond 1993 showed remarkable reductions in the numbers of individuals and species with increasing altitude. Schnitzer and Bongers (2002) revealed the species richness of climber was generally higher in the forest types at lower elevation compared with high elevation.

Putz and Chai (1987) reported that lianas on Lambir National Park (Malaysia) were twice as abundant in the valley as on hilltops. Proctor et al. (1983) found climbers in Gunung National Park, Sarawak, more frequently occur in alluvial forests, where the nutrients came with the floods, than in the higher altitude forest.

Annonaceae showed a high number of species in this area. Gentry (1987) suggested that Annonaceae is unusually dominant in the climber flora in Asian forests. Annonaceae in Sarawak showed the greatest species richness (Gentry 1991) while in Lambir National Park (Sarawak) Leguminosae was the most species richness family, followed by Annonaceae (Putz and Chai 1987). Kammesheidt et al. (2009) in Sabah recorded Leguminosae and Annoanceae the most abundant families. DeWalt et al. (2006) found a similar abundance pattern for Leguminosae and Annonaceae. A less dominant role of Leguminosae was found in Peninsular Malaysia where Arecaceae, Annonaceae and Connaraceae were more abundant (Appanah et al. 1993). Connaraceae, the second most diverse family of climbers, was dramatically absent from the hill forest in Pasoh and Pulau Pangkor.

Padaki (2000) explained one possible reason for the high abundance of climbers in Gunung Mulu was the frequency of treefall due to the flood.

The mechanisms by which the climbers climb their host plants play a major role in their abundance, diversity and distribution (Nabe-Nielsen 2001). In this study, five major mechanisms of climbing systems were recorded. Of these, twining around the host plants were the most common, $64 \%$ of the climbers in the study areas are adapted to this climbing mechanism. Several authors (e.g. Gentry 1991, DeWalt et al. 2000, Parthasarathy et al. 2004, Nabe-Nielsen 2001, Jongkind and Hawthorne 2005, Kuzee and Bongers 2005) have reported similar findings in the different tropical forests. Senbeta et al. (2005) and Nabe-Nielsen (2001) stated twining appear in the forests with small to medium-sized diameter. In this study area, trees within class $5-15 \mathrm{~cm}$ dbh constitute the higher proportion of 54\% of individuals, then the appearance of twiners is reasonable, as Putz (1984) believed the availability of small-diameter supports limits the access of other types of climbers to the canopy.

Higher density of Palmae is largely due to the counting of the rattan like Calamus and Korthalsia. The presence of rattans is a unique feature of climbers in Peninsular Malaysia compared to the African and Neotropical. They are the most common climber in the upper hill dipterocarp forest. Rattans are widespread from West Africa to Fiji from South China to Queensland, Australia, but are most concentrated in Southeast Asia. In the primary forests of Malaysia, rattans are a significant feature. Pasoh and Genting mountain have many rattan species as well (Appanah 1992). Rattans distributed in different elevations depend more on the spatial arrangement of supports that on the diameter of any part of their trellises. This allows them to grow up to the canopy in small openings in the overstorey. Climbers that have adventitious roots are rare in this study. It is not clear why they are not common but Putz and Chai (1987) in Lambir and Putz (1984) in Panama came with the same result.

\section{Conclusions}

The recent study has revealed that Pulau Pangkor forest harbor a high density and floristic diversity of climbers, which contribute significantly to the overall biodiversity of this forests. It also provided baseline information on the biological and ecological importance of climbers. Patterns of distribution and floristic composition of climbers have been related to the macroclimate variables like elevation. Here are other environmental factors not recorded in this study, such as light intensity and humidity, which influence the climber distribution patterns. The importance of climbers can attract researches to further knowledge in various fields like pharmacists and they should be explicitly taken into account in forest management plans.

\section{References}

Appanah, S., Gentry, A. H., Lafrankie, J. V. (1992). Liana diversity and species richness of Malaysian rainforests. Journal of Tropical Forest Science, 6 (2), 116-123.

Baars, R., Kelly, D. \& Sparrow, A. D. (1998). Liane distribution within native forest remnants in two regions of the South Island, New Zealand. New Zealand Journal of Ecology, 22, 71-85.

Balfour, D. A., Bond, W. J. (1993). Factors limiting climber distribution and abundance in a southern African forest. Journal of Ecology, 81, 93-99. 
Benavides, A. M., Alvaro, J., Duque, M., Duivenvoorden, G., Vasco, A., \& Callejas, R. (2005). A first quantitative census of vascular epiphytes in rain forests of Colombian Amazonia. Biodiversity and Conservation, 14, 739-758.

Cai Z, Poorter L, Cao KF, \& Bongers F. (2007). Seedling growth strategies in Bauhinia species: comparing lianas and trees. Annual Botany, 100, 831-838.

Campbell, E. J. F. \& D. M. C. Newbery. (1993). Ecological relationships between lianas and trees in lowland rain forest in Sabah, East Malaysia. Journal of Tropical Ecology, 9, 469-490.

DeWalt, S. J., Schnitzer, S. A. \& Denslow, J. S. (2000). Density and diversity of lianas along a chronosequence in a central Panamanian lowland forest. Journal Tropical Ecology, 16, 1-19.

DeWalt, S. J., Ickes, K., Nilus, R., Harms, K. E., \& Burslem, DFRP. (2006). Liana habitat association and community structure in a Bornean lowland tropical forest. Plant Ecology, 186, 203-216.

Emmons, L. H., \& Gentry, A. H. (1983). Tropical forest structure and the distribution of gliding and prehensile tailed vertebrates. American Nature, 121, 513-524.

Gentry, A. H. (1991). The distribution and evolution of climbing plants. In Putz F.E. and Mooney H.A. (Eds), The Biology of Vines (p. 3-49). Cambridge University Press.

Gentry, A. H. \& C. H. Dodson. (1987). Diversity and biogeography of neotropical vascular epiphytes. Ann. Missouri Botany Garden, 74, 205-233.

Gillespie T. W., Grijalva A. \& Farris C. N. (2000). Diversity, composition and structure of tropical dry forests in Central America. Plant Ecology, 147, 37-47.

Grauel, W. T., \& Puzt, F. E. (2004). Effects of lianas on growth and regeneration of Prioria copaifera in Darien, Panama. Forest Ecology and Management, 190, 99-108.

Homeier, J., Fabian, E., Leuschner, C., Weigelt, P., Patrick, \& Unger, M. (2010). Factors controlling the abundance of lianas along an altitudinal transect of tropical forests in Ecuador. Forest Ecology and Management, 259, 1399-1405.

Jongkind, C. C. H., \& Hawthorne, W. D. (2005). A botanical synopsis of the lianas and other forest climbers. In Parren M.P.E, Traoré D., Bongers F. (Eds), Forest Climbers of West Africa (p. 19-39). CABI Publishing, Wallingford.

Kainer, K. A., Wadt, L. H. O., Gomes-Silva, D. A. P., \& Capanu, M. (2006). Liana loads and their association with Bertholletia excelsa fruit and nut production, diameter growth and crown attributes. Journal of Tropical Ecology 22, 147-154.

Kammesheidt, L., Berhaman, A., Tay, J., Abdullah, G., \& Azwal, M. (2009). Liana abundance, diversity and tree infestation in the Imbak Canyon conservation area, Sabah, Malaysia. Journal of Tropical Forest Science, 21(3), 265-271.

Kuzee, M.E., \& Bongers, F. (2005). Climber abundance, diversity and colonization in degraded forests of different ages in Côte d'Ivoire. In Bongers F., Parren M.P.E., Traoré D. (Eds), Forest Climbers of West Africa: Diversity, Ecology and Management (p. 67-84). CABI Publishing, Wallingford.

Leimbeck, R. M., \& Balslev, H. (2001). Species richness and abundance of epiphytic Araceae on adjacent floodplain and upland forest in Amazonian Ecuador. Biodiversity and Conservation, 10, 1579-1593.

McCune, B., \& Mefford, M. J. (1999). Multivariate Analysis of Ecological Data, Version 4.14. MJM Software, Glenden Beach, Oregon, USA.

Nabe-Nielsen, J. (2001). Diversity and distribution of lianas in a neotropical rainforest, Yasuni National Park, Ecuador. Journal of Tropical Ecology, 17, 1-19.

Ødegaard F. (2000). The relative importance of trees versus lianas as hosts for phytophagous beetles (Coleoptera) in tropical forests. Journal of Biogeography, 27, 283-296.

Padaki, A. \& Parthasarathy, N. (2000). Abundance and distribution of lianas in tropical lowland evergreen forest of Agumbe, central Western Ghats, India. Tropical Ecology, 41(2), 143-154.

Parthasarthy, N., Muthuranmkumar, S., \& Sridhar, M. R. (2004). Patterns of liana diversity in tropical evergreen forest of Peninsular India. Forest Ecology and Management, 190, 15-31. 
Perez-Salicrup, D. R., Sork, L. V., \& Putz, F. E. (2001). Lianas and trees in a liana forest of mazonian Bolia. Biotropica, 33, 34-47.

Proctor, J., Anderson, J.M., Chai, P., Vallack, H. W. (1983). Ecological studies in four contrasting lowland rain forests in Gunung Mulu National Park, Sarawak. I. Forest environment, structure and floristics. Journal of Ecology, 71, 237-260.

Putz, F. E., Mooney, H. A. (1991). The biology of vines. Cambridge University Press, Cambridge, UK.

Putz, F. E. \& Chai, P. (1987). Ecological studies of lianas in Lambir National Park, Sarawak, Malaysia. Journal of Ecology, 75, 523-531.

Putz, F. E. (1984). The natural history of lianas on Barro Colorado Island, Panama. Ecology, 65, 1713-1724.

Putz, F. E. \& Appanah, S. (1987). Buried seeds, dispersed seeds, and the dynamics of a lowland dipterocarp forest in Malaysia. Biotropica, 19, 326- 33.

Putz, F. E., \& Holbrook, N. M. (1991). Biomechanical studies of vines. In Putz, F.E., Mooney, H.A. (Eds), The biology of vines (p. 73-97). Cambridge University Press, Cambridge.

Reddy, M. S. \& Parthasarathy, N. (2003). Liana diversity and distribution in four tropical dry evergreen forest on the Coromanded coast of South India. Biodiversity and Conservation, 12, 1609-1627.

Richards, P. W. (1996). The Tropical Rain Forest: An Ecological Study. Cambridge University Press, Cambridge, Mass.

Sang, W. (2009). Plant diversity patterns and their relationships with soil and climatic factors along an altitudinal gradient in the middle Tianshan Mountain area, Xinjiang, China. Ecology Research, 24, 303-314.

Schnitzer, S. A. \& Bongers, F. (2002). The ecology of lianas and their roles in forests. Trends in Ecology and Evolution, 17, 223-230.

Schnitzer, S. A. (2005). A mechanistic explanation for global patterns of liana abundance and distribution. American Nature, 166, 262-276.

Schnitzer, S. A., \& Carson, W. P. (2001). Treefall gaps and the maintenance of species diversity in a tropical forest. Ecology, 82, 913-919.

Selaya, N. G., Antan, N. P. R., Oomen, R. J., Matthies, M., \& Werger, M. J. A. (2007). Above-ground biomass investments and light interception of tropical forest trees and lianas early in succession. Annual Botany, 99, 141-151.

Selaya, N. G., \& Anten, N. P. R. (2008). Differences in biomass allocation, light interception and mechanical stability between lianas and trees in early secondary tropical forest. Function Ecology, 22, 30-39.

Senbeta, F., Schmitt, C., Denich, M., Demissew, S., Vlek, P., et al. (2005). The diversity and distribution of lianas in the Afromontane rain forests of Ethiopia. Diversity and Distributions, 11, 443-452.

Stevens, G. C. (1987). Lianas as structural parasites: the Bursera simaruba example. Ecology, 68, 77-81.

ter Steege, H. \& Cornelissen, J. H. C. (1989). Distribution and ecology of vascular epiphytes in low land rain forest of Guyana. Biotropica, 21(4), 331-339.

Teramura, A. H., Gold, W. G. \& Forseth, I. N. (1991). Physiological ecology of mesic, temperate woody lianas. In Putz F.E. \& Mooney H.A. (Eds), The biology of lianas (p. 245-285). Cambridge University Press, Cambridge.

Zhu, H. (2008). Species composition and diversity of lianas in tropical forests of Southern Yunnan, South Western China. Journal of Tropical Forest Science, 20(2), 111-122.

Table 1. Specie richness and number of individuals from all five 1-ha plots in Sungai Pinang Permanent Forest Reserve in Pulau Pangkor

\begin{tabular}{|l|c|c|c|c|c|}
\hline & Plot 1 & Plot 2 & Plot 3 & Plot4 & Plot 5 \\
\hline Species No. & 37 & 30 & 22 & 24 & 18 \\
\hline Family No. & 17 & 15 & 13 & 13 & 9 \\
\hline No. of individuals & 1646 & 1288 & 389 & 727 & 297 \\
\hline
\end{tabular}


Table 2. The percentage of soil particles according to Bouyoucos analyses within five plots in study area

\begin{tabular}{lcccr}
\hline Plot & Sand (\%) & \multicolumn{1}{c}{ Clay (\%) } & Silt (\%) & Soil Type \\
\hline Plot 1 & 86.21 & 6.89 & 6.89 & Sandy loamy \\
Plot 2 & 96.63 & 1.69 & 1.69 & Sandy \\
Plot 3 & 98.55 & 0.50 & 0.96 & Sandy \\
Plot 4 & 96.55 & 1.72 & 1.72 & Sandy \\
Plot 5 & 96.35 & 1.81 & 1.81 & Sandy
\end{tabular}

Table 3 The number of species according to climbing types in five 1-ha plots in Sungai Pinang Permanent Forest Reserve in Pulau Pangkor

\begin{tabular}{lccccc}
\hline Climber type & Plot 1 & Plot 2 & Plot 3 & Plot 4 & Plot 5 \\
\hline Twiner & 20 & 17 & 14 & 13 & 11 \\
Hooker & 5 & 5 & 3 & 4 & 3 \\
Tendril & 3 & 3 & 3 & 2 & 1 \\
Root climber & 3 & 0 & 1 & 1 & 0 \\
Rattan & 6 & 5 & 2 & 4 & 3 \\
\hline
\end{tabular}

Table 4. The distribution of climber types in different plots according the number of individuals in five 1-ha sampling plots in Sungai Pinang Permanent Forest Reserve

\begin{tabular}{llcccc}
\hline Climber type & Plot 1 & Plot 2 & Plot 3 & Plot 4 & Plot 5 \\
\hline Twiner & 630 & 516 & 203 & 356 & 114 \\
Hooker & 72 & 78 & 13 & 13 & 55 \\
Tendril & 91 & 40 & 23 & 36 & 13 \\
Root climber & 260 & 0 & 1 & 4 & 0 \\
Rattan & 561 & 698 & 148 & 318 & 115 \\
\hline
\end{tabular}

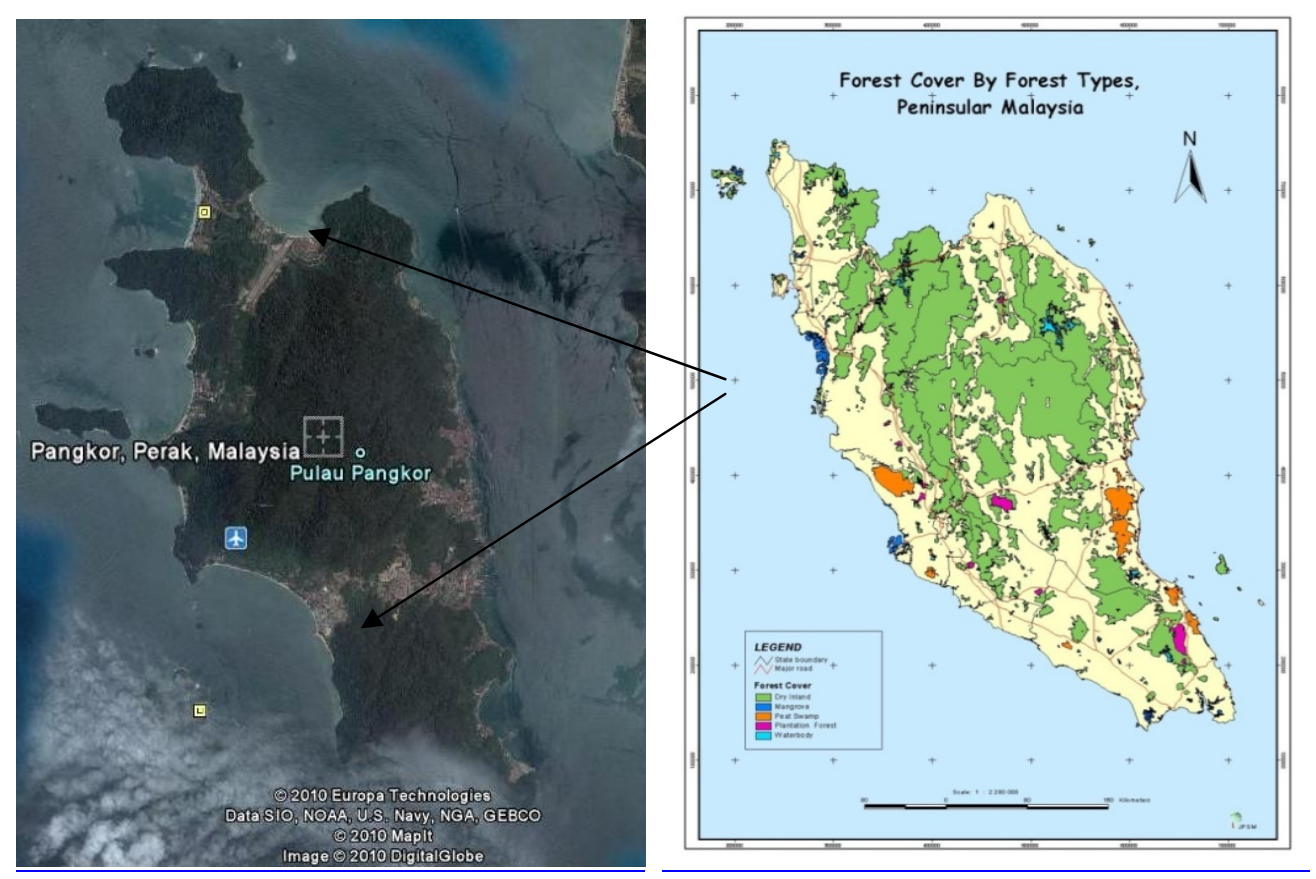

Figure 1. The map of Peninsular Malaysia and location of study area 


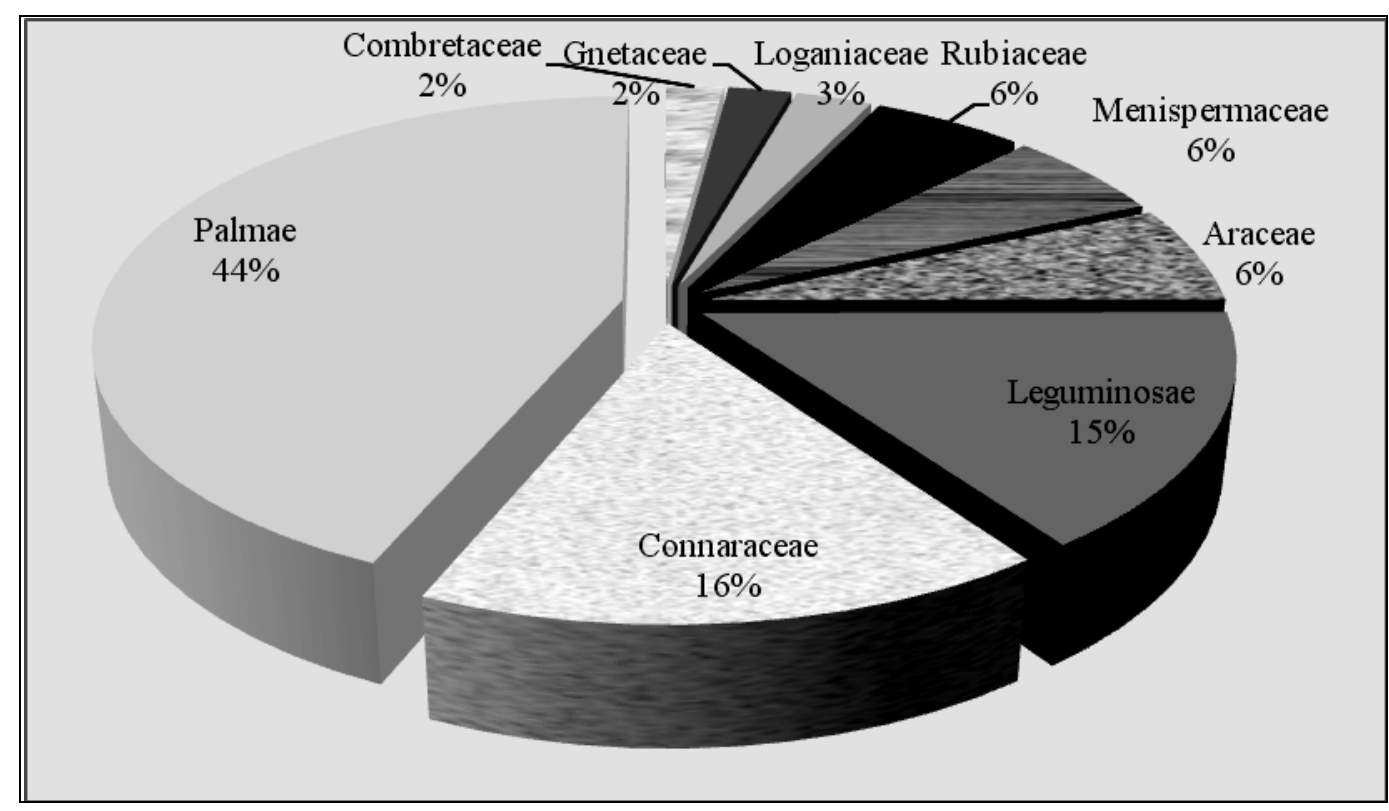

Figure 2. The proportion of the climber families in the study area by the number of individuals

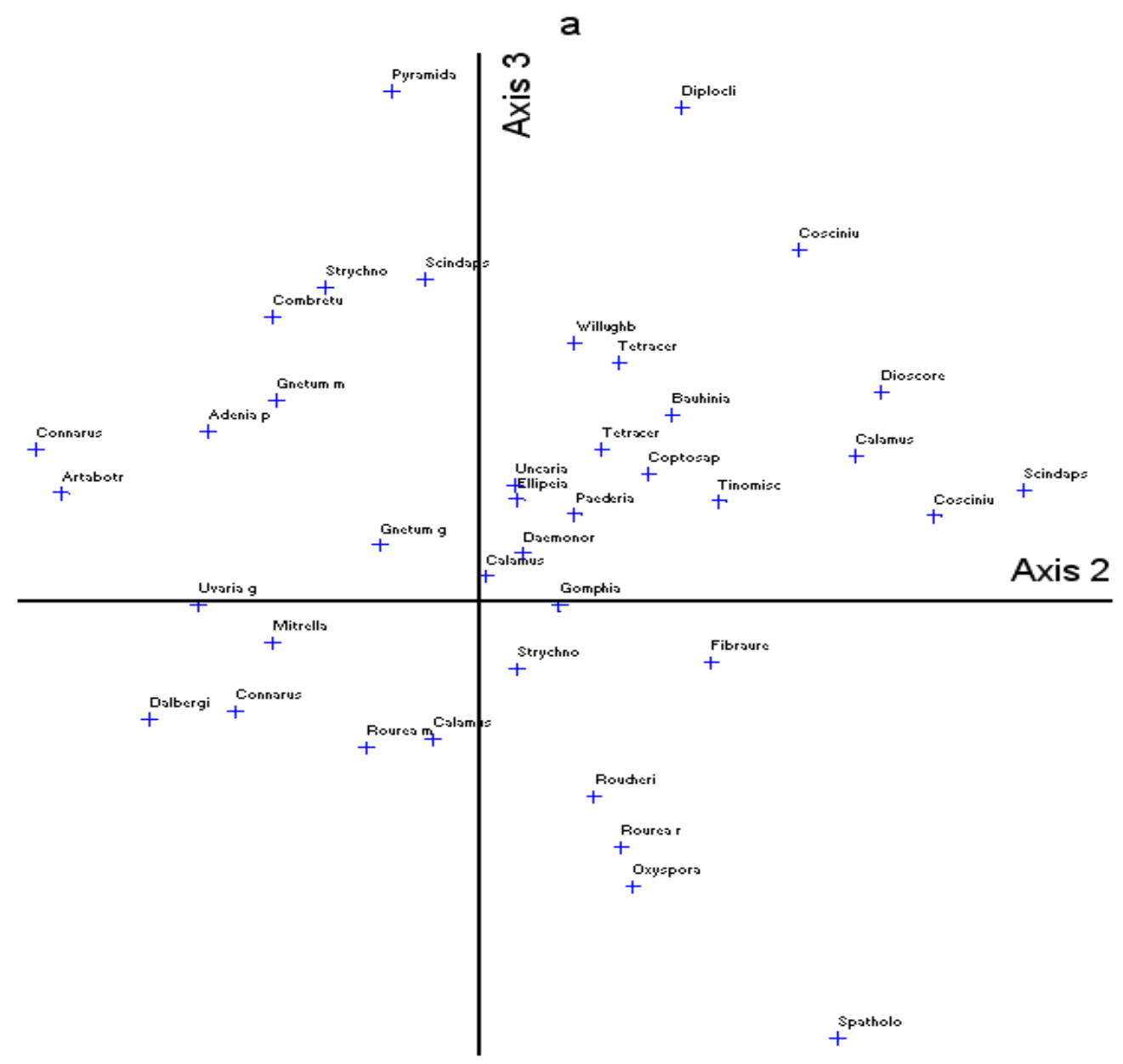

Figure 3. Ordination of 500 subplots based on elevation in canonical correspondence analysis (CCA) in Sungai Pinang Permanent Forest Reserve 


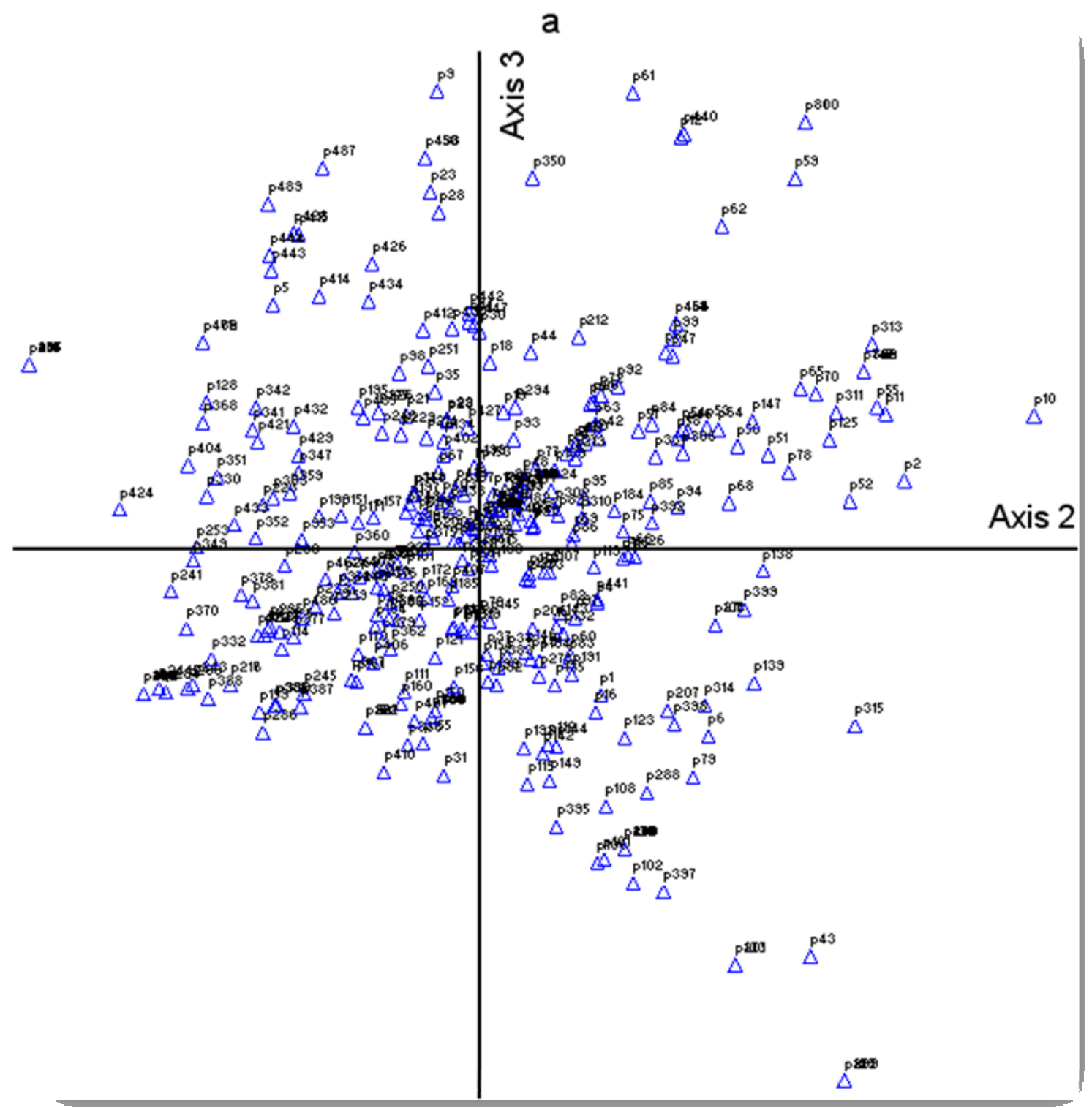

Figure 4. Ordination based on canonical correspondence analysis (CCA) relating climber distribution in subplots in Sungai Pinang Permanent Forest Reserve 
Appendix 1. Climber species and climbing mode in five he plot in Sungai Pinang Permanent Forest Reserve in Pulau Pangkor

Family

Species

Type of climbing

\begin{tabular}{|c|c|c|}
\hline Annonaceae & Artabotrys suaveolens (Blume) Blume & Hooker \\
\hline Annonaceae & Uvaria griflora Roxb. ex Hornem & Hooker \\
\hline Annonaceae & Ellipeia cuneifolia Hook.f. and Thomson & Unknown \\
\hline Annonaceae & Mitrella kentii (Blume) Miq. & Unknown \\
\hline Annonaceae & $\begin{array}{l}\text { Pyramidanthe prismatica (Hook.f. and Thomson) J. } \\
\text { Sinclair }\end{array}$ & Unknown \\
\hline Apocynaceae & Willughbeia edulis Roxb. & Twiner \\
\hline Araceae & Scindapsus perakensis Hook.f. & Root climber \\
\hline Comberetaceae & Combretum nigrescens King & Hooker \\
\hline Connaraceae & Connarus grandis Jack & Twiner \\
\hline Connaraceae & Connarus ferrugineus Jack & Twiner \\
\hline Connaraceae & Connarus semidecrus Jack & Twiner \\
\hline Connaraceae & Rourea mimosoides (Vahl) Planch. & Twiner \\
\hline Connaraceae & Rourea rugosa Planch. & Twiner \\
\hline Dichapetalaceae & $\begin{array}{l}\text { Dichapetalum laurocerasus (Planch. ex Hook.f.) } \\
\text { Engl. }\end{array}$ & Twiner \\
\hline Dilleniaceae & Tetracera scens (L.) Merr. & Twiner \\
\hline Dilleniaceae & Tetracera indica Merr. & Twiner \\
\hline Dioscoraceae & Dioscorea bulbifera L. & Twiner \\
\hline Leguminosae & Bauhinia kockiana Korthalsia & Tendril \\
\hline Leguminosae & Spatholobus ferrugineus (Zoll. and Moritzi) Benth. & Twiner \\
\hline Leguminosae & Dalbergia parviflora Roxb. & Twiner \\
\hline Gnetaceae & Gnetum microcarpum Blume & Twiner \\
\hline Linaceae & Roucheria griffithiana Planch. & Hooker \\
\hline Loganiaceae & Strychnos axillaris Colebr. & Hooker \\
\hline Loganiaceae & Strychnos flavescens King andGamble & Hooker \\
\hline Menispermaceae & Fibraurea chloroleuca Miers. & Tendril \\
\hline Menispermaceae & $\begin{array}{l}\text { Coscinium blumeanum Miers ex Hook.f. and } \\
\text { Thomson }\end{array}$ & Twiner \\
\hline Menispermaceae & Diploclisia kunstleri (King) Diels & Twiner \\
\hline Menispermaceae & Coscinium fenestratum (Gaertner) Colebr. & Twiner \\
\hline Menispermaceae & Tinomiscium petiolare Hook.f. and Thomson & Twiner \\
\hline Ochnaceae & Gomphia microphylla Ridl. & Twiner \\
\hline Orchidaceae & Vanilla griffithii Rchb.f. & Twiner \\
\hline Palmae & Calamus castaneus Griff. & Rattan \\
\hline Palmae & Calamus insignis Griff. & Rattan \\
\hline Palmae & Calamus javensis Blume & Rattan \\
\hline Palmae & Daemonorops calicarpa (Griff.) Mart. & Rattan \\
\hline Palmae & Korthalsia rigida Blume & Rattan \\
\hline Palmae & Korthalsia scortechinii Becc. & Rattan \\
\hline Passifloraceae & Adenia penangiana (Wall. ex G. Don) W.J. de Wilde & Twiner \\
\hline Piperaceae & Piper magnibaccum $C$. DC. & Root climber \\
\hline Rhamnaceae & Ventilago malaccensis Ridl. & Twiner \\
\hline Rubiaceae & Uncaria cordata (Lour.) Merr & Hooker \\
\hline Rubiaceae & Coptosapelta griffithii Hook.f. & Twiner \\
\hline Rubiaceae & Oxyceros curtisii (King and Gamble) K.M. Wong & Twiner \\
\hline Rubiaceae & Paederia foetida $\mathrm{L}$. & Twiner \\
\hline Vitaceae & Tetrastigma lawsoni (King) Burkill ex A.W. Hill & Twiner \\
\hline
\end{tabular}

